Mengoptimalkan Perawatan Komponen-Komponen Pada Sistem Kelistrikan Guna Mencegah Terjadinya Low Insulation Di Kapal SS. Surya Satsuma

Darul Prayogo ${ }^{\mathrm{a}}$ dan Krisman Gelesah ${ }^{\mathrm{b}}$

\title{
MENGOPTIMALKAN PERAWATAN KOMPONEN-KOMPONEN PADA SISTEM KELISTRIKAN GUNA MENCEGAH TERJADINYA LOW INSULATION DI KAPAL SS. SURYA SATSUMA
}

\author{
Darul Prayogo a dan Krisman Gelesah ${ }^{\mathrm{b}}$ \\ ${ }^{a}$ Dosen Program Studi Teknika PIP Semarang \\ ${ }^{\mathrm{b}}$ Taruna Program Studi Teknika STIP Jakarta
}

\begin{abstract}
ABSTRAK
Pentingnya kebutuhan listrik diatas kapal sering tidak disertai dengan perawatan yang baik atau secara intensif. Hal ini dapat menyebabkan terjadi masalah pada sistem kelistrikan yang ada di kapal. Biasanya masalah kelistrikan terjadi pada kapal - kapal yang sudah cukup lama beroperasi (kapal-kapal tua). Salah satu masalah kelistrikan yang popular di atas kapal adalah kebocoran arus listrik yang yang lebih sering kita kenal dengan istilah "low insulation"

Penelitian ini bertujuan untuk mengetahui penyebab dan pengaruh low insulation dalam sistem kelistrikan diatas kapal dan mengetahui perawatan yang benar dalam sistem kelistrikan kapal.

Sasaran dari pengkajian ini adalah sebagai sumbangan terhadap ilmu pengetahuan terkait perawatan komponen-komponen pada sistem kelistrikan diatas kapal dan sebagai acuan atau pedoman dalam melakukan perawatan terhadap komponen-komponen pada sistem kelistrikan diatas kapal.

Kondisi sekitar (seperti suhu, kelembaban, dan cuaca) menyebabkan suatu komponen listrik mengalami kerusakan akibat terbentuknya korosi. Umur dari suatu komponenkomponen listrik dapat mempengaruhi terjadinya low insulation di atas kapal. batas waktu tersebut menyebabkan komponen itu tidak dapat berfungsi secara maksimal bahkan mengalami kerusakan. Faktor korosi dapat menyebabkan terjadinya low insulation dikapal SS. Surya Satsuma. Bagian komponen listrik yang terbuat dari besi mengalami korosi dan lama-kelamaan korosi tersebut mulai menyebar pada isolator di komponen listrik tersebut dan mengakibatkan isolator sebagai penghambat listrik tidak berfungsi.
\end{abstract}

Kata kunci : perawatan, low insulation, korosi

\section{PENDAHULUAN}

Di dalam melakukan pelayaran dari satu pelabuhan ke pelabuhan yang lain dengan jarak yang cukup jauh, maka kapal harus dapat beroperasi dengan baik. Agar kapal dapat beroperasi dengan baik harus didukung dengan permesinan yang baik. Di atas kapal terdapat mesin penggerak utama (Main Engine) serta permesinan bantu (Auxiliary Engine), guna memenuhi segala kebutuhan di atas kapal. Jika mesin penggerak utama (Main Engine) berperan sebagai penggerak kapal, maka permesinan bantu (Auxiliary Engine) merupakan permesinan bantu di atas kapal yang berguna untuk memenuhi segala kebutuhan untuk menunjang kinerja dari kapal tersebut. Salah satu kebutuhan yang diperlukan untuk menunjang kinerja kapal adalah kebutuhan akan listrik. Namun kebutuhan listrik ini juga harus ditunjang 
dengan faktor-faktor seperti perencanaan akan intalasi listrik di atas kapal atau sistem distribusi daya listrik di atas kapal. Selain harus ditunjang dengan beberapa faktor penting, kebutuhan akan listrik juga harus diikuti dengan pengadaan komponen listrik yang baik pula guna memenuhi kelengkapan komponenkompanen untuk system distribusi dan sesuai persyaratan pada peraturan rekayasa kemaritiman. Lebih khusus lagi yaitu merencanakan instalasi penerangan, sistem komunikasi, navigasi, monitoring, dan sistem pendukung lainnya pada geladak anjungan (navigation deck). Kebutuhan listrik di atas kapal dapat dipenuhi dengan suplai listrik dari generator.

Pentingnya kebutuhan listrik di atas kapal sering tidak disertai dengan perawatan yang baik atau secara intensif. Hal ini dapat menyebabkan terjadi masalah pada sistem kelistrikan yang ada di kapal. Biasanya masalah kelistrikan terjadi pada kapal-kapal yang sudah cukup lama beroperasi (kapal-kapal tua). Salah satu masalah kelistrikan yang popular di atas kapal adalah kebocoran arus listrik yang yang lebih sering kita kenal dengan istilah "low insulation".

\section{METODE PENELITIAN}

Metode analisa data yang penulis gunakan dalam penelitian ini adalah deskriptif kualitatif dimana data data yang diperoleh disusun secara sistematis dan teratur, kemudian penulis membuat analisa kualitatif agar diperoleh kejelasan tentang masalah yang dilakukan dalam penelitian ini. Analisa data yang dilakukan dalam penelitian ini adalah analisa terhadap low insultion. Dari penjelasan tersebut diharapkan mampu menggambarkan secara keseluruhan pokok bahasan serta pemecahan masalah penelitian ini.

\section{HASIL PENELITIAN DAN PEMBAHASAN}

\section{A. HASIL PENELITIAN}

1. Kondisi lingkungan sekitar dapat mempengaruhi terjadinya low insulation di atas kapal

Pada tanggal 01 Januari 2016 kapal SS. Surya Satsuma berlayar dari Bontang menuju ke Hiroshima-Japan. Kondisi kapal berlayar dengan cuaca baik. Pada saat saat itu Jepang sedang dalam iklim dingin (musim salju). Tiba-tiba pada pukul 14:00 alarm low insulaton berbunyi. Oiler jaga dan chief engineer melihat alarm low insulation (resistansi rendah) dari sistem kelistrikan kapal. Masinis 3 pergi melihat CRT (Computer Remote Temperature) dan di sana terdapat keterangan alarm low insulation $100 \mathrm{~V}$ MSB. Setelah itu Masinis 3 beserta kadet melakukan pengecekan sistem kelistrikan di kapal khususnya pada sistem kelistrikan 100V. Pemeriksaan dilakukan dengan cara mematikan sakelar listrik yang menggunakan arus $100 \mathrm{~V}$ secara bergantian sambil memantau nilai insulation pada panel. Melalui pemeriksaan itu, Masinis 3 mendapati low insulation terjadi pada sistem lampu navigasi kapal.

Ternyata kami menemukan banyak kadar air yang terdapat di dalam rumah lampu (casing). Kemudian kami melakukan pengecekan ternyata komponen yang berfungsi sebagai kedap airnya sudah rusak.

2. Umur dari suatu komponen-komponen listrik dapat mempengaruhi terjadinya low insulation di atas kapal

Pada tanggal 14 Januari 2016 kapal SS. Surya Satsuma dalam perjalanan menuju ke Jepang. Sekitar pukul 05:00 alarm low insulation aktif. Pada saat itu seda terjadi peralihan musim dari musim 
Mengoptimalkan Perawatan Komponen-Komponen Pada Sistem Kelistrikan Guna Mencegah Terjadinya Low Insulation Di Kapal SS. Surya Satsuma

Darul Prayogo ${ }^{\mathrm{a}}$ dan Krisman Gelesah ${ }^{\mathrm{b}}$

salju ke musim semi di Jepang. Masinis 3 pergi ke ECR untuk melihat di mana terjadi low insulation. Pada CRT ada keterangan yang menyatakan alarm low insulation terjadi pada sistem lampu navigasi kapal. Masinis 3 Mematikan alarm low insulation tetapi tidak meriset alarm tersebut. Hal tersebut dilakukan Masinis 3 karena apabila alarm tersebut diriset tanpa diperbaiki terlebihi dahulu, maka alarm akan terus aktif.

Pukul 09:00 Masinis 3 melakukan pengecekan terhadap lampu-lampu navigasi untuk menemukan titik masalah dari low insulation tersebut. Setelah melakukan pemeriksaan selama 10 menit, maka ditemukan lampu navigasi sebelah kananlah yang menyebabkan alarm low insulation aktif.

3. Korosi dapat menyebabkan terjadinya low insulation di atas kapal

Korosi merupakan suatu proses yang menyebabkan terjadinya karat pada suatu logam. Pada tanggal 15 Februari 2016, saat itu SS. Surya Satsuma sedang berada di pelabuhan Hatsukaichi, Jepang. Tiba-tiba terdengar alarm dari kamar mesin. Pada saat itu masinis yang sedang jaga adalah Masinis 2 dan dia mendapati alarm tersebut adalah alarm low insulation pada $100 \mathrm{~V}$. Masinis 2 mematikan alarm tersebut lalu melaporkannya kepada Masinis 3 Hal tersebut dikarenakan bagian kelistrikan adalah tanggung jawab dari Masinis 3. Namun karena masih di pelabuhan, maka masalah tersebut tidak dapat langsung dikerjakan. Maka Masinis 3 hanya membuat jadwal pemeriksaan untuk masalah tersebut ketika kapal sudah meninggalkan pelabuhan. Pada saat kami melakukan pemeriksaan kami mendapati low insulation terjadi pada lampu penerangan pada bagian kanan kapal. low insulation terjadi akibat adanya bagian kabel pada junction box untuk lampu tersebut yang mangalami korosi. Low insulation ini baru diketahui karena lampu tersebut jarang dioperasikan, dan pengoperasiannya hanya dilakukan pada saat kapal sandar kanan ketika berada di pelabuhan.

\section{KESIMPULAN DAN SARAN}

\section{A. KESIMPULAN}

1. Kondisi sekitar (seperti suhu, kelembaban, dan cuaca) menyebabkan suatu komponen listrik mengalami kerusakan akibat terbentuknya korosi. Cara penanganannya adalah dengan melakukan pemeriksaan nilai resistansi secara berkala dan melakukan perawatan secara teratur.

2. Umur dari suatu komponenkomponen listrik dapat mempengaruhi terjadinya low insulation di atas kapal. Faktor ini dimana suatu komponen listrik telah memiliki batas waktu pemakaian tertentu dan jika sudah melewati batas waktu tersebut menyebabkan komponen itu tidak dapat berfungsi secara maksimal bahkan mengalami kerusakan. Cara penanganannya adalah dengan cara mengganti komponen tersebut dengan yang baru.

3. Faktor korosi dapat menyebabkan terjadinya low insulation di kapal SS. Surya Satsuma. Bagian komponen listrik yang terbuat dari besi mengalami korosi dan lamakelamaan korosi tersebut mulai menyebar pada isolator di komponen listrik tersebut dan mengakibatkan isolator sebagai penghambat listrik tidak berfungsi, oleh sebab itu cara penanganannya adalah dengan cara melakukan perawatan secara teratur dan jika 
korosi tersebut sudah parah, maka segera ganti dengan suku cadang yang baru.

\section{B. SARAN}

1. Meningkatkan perawatan secara berencana (Planing Maintenance Schedule) dan berkala di atas kapal, serta melakukan pemeriksaan secara berkala pada sistem kelistrikan yang berada di luar kapal atau yang berhubungan langsung dengan kondisi lingkungan.

2. Perlu adanya penyediaan suku cadang yang cukup oleh pihak perusahaan pelayaran, sehingga dapat mengganti semua komponenkomponen listrik yang sudah tidak layak pakai lagi.

3. Ditujukan pada pihak perusahaan perlu dilakukan pemeriksaan resistansi terjadwal paling sedikit tiga bulan sekali pada sistem kelistrikan mencakup tegangan $440 \mathrm{~V}$ pada semua motor-motor listrik yang ada di kapal dan pada tegangan $100 \mathrm{~V}$ pada sistem penerangannya.

\section{DAFTAR PUSTAKA}

Endratmo. 1999. Sistem Kelistrikan Kapal. Jakarta: Erlangga

Handoyo, Jusak Johan. 2014. Teknik Kelistrikan Kapal. Jakarta: Djangkar

Salim, Agus. 2003. Pengetahuan Praktis Kelistrikan Kapal. Jakarta: PT. Asuka Bahari Nusantara

Harten, Setiawan. 1983. Instalasi Listrik Arus Kuat. Jakarta: CV. Trimitra Mandiri

Arya. 2015. Pengertian dan Definisi Listrik. Bandung: Mandar Maju

Kumala. 2015. Kerusakan pada Motor Listrik. Jakarta: CV. Karya Jaya Abadi. 
Dwi Maryuana Restu ${ }^{\mathrm{a}}$, Abdi Seno ${ }^{\mathrm{b}}$ dan Andy Wahyu Hermanto ${ }^{\mathrm{c}}$

\title{
ANALISA PENURUNAN KUALITAS AIR PADA PENGOPERASIAN KETEL UAP DI MV. NYK VEGA
}

\author{
Dwi Maryuana Restu ${ }^{a}$, Abdi Seno ${ }^{b}$ dan Andy Wahyu Hermanto ${ }^{c}$ \\ ${ }^{a}$ Taruna Prodi Teknika PIP Semarang \\ b dan c Dosen Program Studi Teknika PIP Semarang
}

\begin{abstract}
Steam boiler is a closed vessel that can produce hot steam with the pressure of more than one atmosphere by heating the water within it. Water in the process greatly affect the condition of the kettle, so the quality must always be maintained.

The research method used in this research is descriptive qualitative method. The data analysis technique used SWOT method to analyze the factors causing the decreasing of water quality of boiler and the effort made to overcome these factors by identifying the strengths, weaknesses, opportunities, and threats.

Based on the result of the research, it can be concluded that water boiler degradation is caused by: 1) Distilled water not yet widely available on board is caused by leakage of evaporator pipe on FWG and mechanical seal damage at distillation pump. 2) Freshwater conditions from land are not eligible for boiler water. To overcome these factors, it is necessary to check to determine which pipe is leaking, patching the leaking pipe using a copper plug, opening and closing the inlet valve and evaporator outlet slowly to avoid thermal shock, mechanical seal replacement of the distillation pump, and testing the boiler water, addition of chemical dosing and water boiler blowdown.
\end{abstract}

\section{Keywords: boiler, water quality, SWOT}

\section{PENDAHULUAN}

Tersedianya uap panas merupakan hal yang mutlak bagi kelancaran operasional permesinan yang membutuhkan, misalnya untuk pemanas bahan bakar F.O, pemanas minyak lumas, pemanas akomodasi saat musim dingin, pemanas air tawar, dan lainlain. Kegiatan pelayaran dapat terganggu jika produksi uap panas mengalami masalah, karena pengaruh peralatan dan kerja dari komponen ketel uap yang kurang baik atau sebab yang lain yang menyebabkan ketel uap mengalami gangguan.

Untuk dapat memproduksi uap diperlukan media yang dipanaskan yaitu air tawar. Air yang digunakan pada proses pembentukan uap sangat berpengaruh terhadap kondisi ketel. Dengan demikian, kualitas air harus diperhatikan dan dijaga agar selalu dalam kondisi baik, sehingga ketel akan selalu dalam kondisi baik pula.

Dalam kenyataannya, ketel uap sering kali mengalami gangguan-gangguan, seperti saat dilakukan pengujian air ketel didapat hasil bahwa kadar alkalinitas, $\mathrm{pH}$ yang terkandung di dalam air berada di bawah batas normal. Apabila hal ini tidak segera diatasi, maka akan mempengaruhi kondisi ketel uap, seperti timbulnya kerak pada pipa-pipa di dalam drum uap sehingga dapat memperlambat waktu pembentukan uap, serta perusahaan akan mengeluarkan biaya tambahan untuk penambahan Chemical Dosing.

Dilatarbelakangi oleh perbedaan antara pernyataan secara teori yang berbeda 
dengan kenyataan yang terjadi, maka penulis tertarik untuk melakukan penelitian dengan judul "Analisa Penurunan Kualitas Air pada Pengoperasian Ketel Uap di MV. NYK Vega".

\section{METODOLOGI}

Metode yang digunakan pada pelitian ini yaitu menggunakan metode deskriptif kualitatif, adapun tujuannya untuk mengungkapkan kejadian atau fakta, keadaan yang terjadi saat penelitian berlangsung dengan menyajikan apa yang sebenarnya terjadi. Untuk mendapatkan sumber data dalam penelitian ini dilakukan dengan observasi, wawancara dan studi pustaka.

Teknik analisis data yang akan dipakai oleh peneliti yaitu dengan menggunakan analisis SWOT. Menurut Fatimah (2016:27), Analisis SWOT adalah suatu bentuk analisis situasi dengan mengidentifikasi berbagai faktor-faktor secara sistematis terhadap kekuatankekuatan (strenghts), kelemahankelemahan (weaknesses), peluang-peluang (opportunities), serta ancaman-ancaman (threats) dari lingkungan untuk merumuskan strategi yang akan diambil. Strategi tersebut antaralain:

1. Strategi optimalkan kekuatan untuk memanfaatkan peluang (Strategi Ekspansi/pertumbuhan),

2. Strategi menggunakan kekuatan untuk mencegah dan mengatasi ancaman (Strategi Diversifikasi),

3. Strategi mengurangi kelemahan dengan memanfaatkan peluang (Strategi Aliansi/stabilitas),

4. Strategi mengurangi kelemahan untuk mengatasi ancaman (Strategi Defensive).

Pada pengolahan data menggunakan metode SWOT dilakukan dengan memberikan penilaian-penilaian faktor menggunakan tabel-tabel untuk menentukan Faktor Kunci Keberhasilan
(FKK) seperti yang dituliskan pada modul LAN (2018), yaitu: Bobot Faktor (BF), Nilai Dukungan faktor (ND), Nilai Relatif Keterkaitan faktor (NRK), Total Bobot Nilai (TNB), serta Peta Kuadran Strategi.

\section{HASIL DAN DISKUSI}

\section{Faktor-faktor apakah yang menyebabkan menurunnya kualitas air ketel?}

a. Air destilasi yang belum banyak

Air destilasi adalah air yang dihasilkan dari proses destilasi di dalam Fresh Water Generator (FWG). Air ini adalah salah satu air yang baik untuk digunakan sebagai air ketel. Namun dari hasil observasi yang peneliti lakukan, saat kapal berada di dock-yard tanggal 4 Agustus 2016 sampai dengan 19 Agustus 2016 dilakukan perawatan terhadap permesinan-permesinan kapal termasuk pada FWG. Setelah kapal keluar dari dock-yard, FWG baru diperiksa dengan melakukan uji pengoperasian pada tanggal 27 Agustus 2016 saat kapal dalam perlayaran dari Xiamen (China) ke Kobe (Jepang) karena kondisi air laut di daerah sebelumnya (daerah China) kotor dan tidak memungkin untuk mengoperasikan FWG. Ternyata setelah diuji pengoperasian tersebut terjadi beberapa gangguan pada FWG, sehingga harus dimatikan terlebih dahulu dan belum bisa digunakan untuk memproduksi air tawar. Dari hasil observasi dan wawancara yang dilakukan peneliti dengan KKM, penyebab dari gangguan pada FWG tersebut adalah karena bocornya pipa pada evaporator dan rusaknya mechanical seal pada pompa destilasi:

1) Bocornya pipa pada evaporator FWG 
Dwi Maryuana Restu ${ }^{\mathrm{a}}$, Abdi Seno ${ }^{\mathrm{b}}$ dan Andy Wahyu Hermanto ${ }^{\mathrm{c}}$

Bocornya pipa pada evaporator menyebabkan keluarnya air evaporator (air dari pendingin jaket mesin induk) ke dalam evaporator dan akibatnya proses penguapan air laut menjadi terganggu. Kebocoran pipa evaporator di MV. NYK Vega diketahui pada tanggal 27 Agustus 2016 dan baru dapat diatasi pada tanggal 29 Agustsus 2016.

2) Rusaknya mechanical seal pada pompa destilasi

Pompa destilasi adalah pompa berjenis sentrifugal yang digunakan untuk menghisap air hasil proses destilasi yang terkumpul pada bagian kondensor FWG yang kemudian dipompa ke tangki air tawar atau tangki air minum. Rusaknya mechanical seal pada pompa menyebabkan air yang telah diproduksi pada kondensor tidak dapat dialirkan ke tangki air tawar. Kerusakan ini terjadi pada tanggal 2 September 2016. Sehingga suplai air destilasi di kapal tidak banyak tersedia.

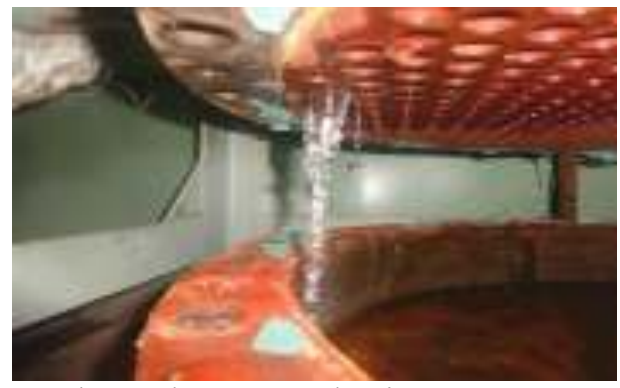

Gambar Kebocoran pada Pipa Evaporator $F W G$

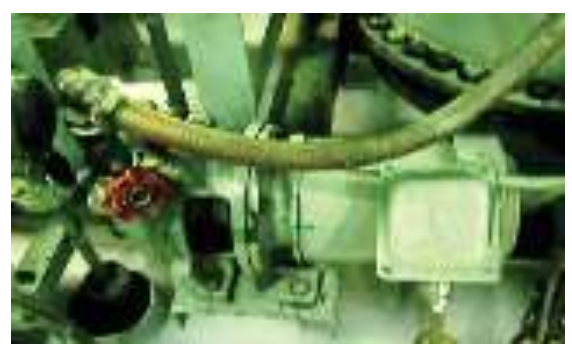

Gambar Pompa Destilasi
Akibat dari gangguan pada FWG tersebut adalah air destilasi tidak banyak diproduksi di kapal. Hal ini diperkirakan sebagai penyebab air yang baik digunakan sebagai air pengisian ketel tidak tersedia, dan air di dalam tangki air tawar masih air yang disuplai dari darat. Seperti yang disampaikan oleh KKM dan Masinis 3 bahwa kurangnya air destilasi yang disebabkan oleh rusaknya $F W G$ setelah dry-dock diperkirakan menyebabkan air yang baik untuk pengisian ketel uap tidak tersedia di kapal. Peneliti juga mendapatkan data dari studi pustaka dengan melihat NALFLEET Log sheet NYK Vega tahun 2012 setelah kapal melaksanakan dry-dock yang menunjukkan adanya penurunan kualitas air ketel.

b. Kondisi air tawar dari darat tidak memenuhi syarat untuk air ketel

Air yang baik digunakan sebagai air pengisian ketel adalah air yang berasal dari proses destilasi yaitu air dari hasil produksi Fresh Water Generator dan air dari proses kondensasi yaitu air yang terbentuk dari uap bekas yang didinginkan di dalam kondensor dan menjadi air kondensat. Namun dari hasil observasi yang peneliti lakukan di MV. NYK Vega pada saat setelah dry-dock, air disuplai dari darat yang kondisinya kurang sesuai jika digunakan sebagai air pengisian dan air ketel. Hal tersebut juga disebutkan oleh Masinis 3 dalam wawancara yang dilakukan peneliti, bahwa hasil pengujian air yang berada di bawah batas normal merupakan akibat dari penggunaan air dari darat yang sebenarnya tidak memenuhi syarat. 
Dari hasil studi pustaka yang peneliti kutip dari http://lokerpelaut.com/perawatan-airketel-uap-atauboiler.html yang dipublikasikan tanggal 16 Agustus 2017, menyatakan bahwa air tawar yang didapatkan dari berbagai pelabuhan dengan tanpa kandungan yang jelas seperti banyak mengandung chloride, asam atau yang akan sangat berpengaruh pada perawatan air ketel.

c. Penginjeksian chemical dosing yang kurang baik

Pemberian chemical dosing dilakukan sesuai dengan hasil uji air ketel, dan mengacu pada instruksi dari program perawatan air ketel yang disusun oleh perusahaan. Namun dari hasil observasi yang peneliti lakukan, terkadang penginjeksian chemical dosing tersebut mengalami gangguan, dan mengakibatkan berkurangnya jumlah chemical yang terinjeksi ke dalam air pengisian.

d. Air pengisian kotor

Air yang digunakan sebagai media pembentukan uap di dalam ketel tidak sepenuhnya bebas dari kotoran, baik yang bersifat padat maupun yang larut dalam air. Dari hasil observasi yang peneliti lakukan melalui pengujian air ketel, didapatkan bahwa kondisi air pengisian dalam kondisi kotor.

e. Air kondensat yang belum banyak tersedia di kapal

Air kondensat yaitu air yang terbentuk dari uap yang sudah digunakan sebagai media evaporator dan berubah wujud dari uap menjadi air karena terjadi perpindahan panas, kemudian dinginkan di dalam kondensor dan menjadi air kondensat. Namun dari hasil observasi peneliti, air kondensat belum banyak tersedia di kapal karena mengingat kapal baru selesai melaksanakan dry-dock. f. Tidak dilakukan pengujian air sebelum air dari darat disuplai ke kapal

Dari hasil observasi yang peneliti lakukan, pada saat setelah dry-dock, air tawar untuk kebutuhan di atas kapal disuplai dari darat. Air tersebut digunakan juga sebagai air pengisian untuk ketel karena belum tersedianya air hasil destilasi/kondensasi. Namun pada saat sebelum bunker, belum dilakukan pengujian untuk air tersebut, sehingga belum diketahui apakah air tersebut layak digunakan sebagai air pengisian atau membutuhkan perawatan lebih.

g. Lamanya kapal berlabuh

Dari hasil observasi yang peneliti lakukan, tanggal 28 Agustus 2016 hingga tanggal 1 September 2016 kapal memasuki kawasan Jepang melakukan bongkar muat di empat terminal yaitu di Kobe, Nagoya, Shimizu, dan Tokyo. Pada saat itu air ketel sama sekali tidak dilakukan blowdown. Sehingga tidak dapat membuang kotoran-kotoran yang terdapat dalam air ketel.

h. Pencegahan pencemaran di sekitar pelabuhan

Air ketel yang telah mendapat perawatan menggunakan chemical dosing kemungkinan mempunyai kandungan-kandungan yang dapat menyebabkan pencemaran apabila dibuang ke perairan pelabuhan. Dengan demikian untuk menghindari pencemaran air di sekitar pelabuhan maka blowdown air ketel tidak dilakukan pada saat kapal berlabuh, dan hanya dilakukan pada saat kapal berlayar di laut lepas. Dari hasil observasi yang peneliti lakukan, blowdown air ketel di MV. NYK Vega tidak dilakukan pada saat kapal berlabuh, dan hanya dilakukan pada saat kapal berlayar di laut lepas. 
Dwi Maryuana Restu ${ }^{\mathrm{a}}$, Abdi Seno ${ }^{\mathrm{b}}$ dan Andy Wahyu Hermanto ${ }^{\mathrm{c}}$

i. Air pengisian yang cukup

Air adalah kebutuhan utama dalam proses pembentukan uap pada ketel uap. Dari hasil observasi yang peneliti lakukan selama peneliti melaksanakan praktek laut, ketersediaan air pengisian ketel di MV. NYK Vega selalu tercukupi. Air pengisian tersebut bersumber dari proses kondensasi uap kembali yang sebelumnya uap tersebut digunakan sebagai media pemanas, selain itu kebutuhan air pengisian juga dicukupi dengan air dari tangki penampungan air tawar, sedangkan air di tangki penampungan air tawar bersumber dari darat.

j. Terdapatnya SOP yang baku

Dari hasil observasi yang peneliti lakukan, Standard Operational Procedure (SOP) yang digunakan untuk pengoperasian ketel uap di MV. NYK Vega dipaparkan dalam Working Instruction yang terdapat dalam folder Electronic-Safety Management System (E-SMS) di komputer kapal. Standard pengoperasian tersebut disusun oleh chief engineer dengan mengacu pada instruction manual book dan disesuaikan dengan kondisi lapangan. Kemudian dicetak dan ditempelkan didekat panel pengoperasian ketel uap.

k. Pemberian Chemical Dosing yang sesuai

Pemberian chemical dosing dilakukan sesuai dengan hasil uji air ketel, dan mengacu pada instruksi dari program perawatan air ketel yang disusun oleh perusahaan. Adapun hasil observasi yang peneliti lakukan, chemical yang digunakan untuk perawatan air ketel di MV. NYK Vega adalah produk dari UNITOR yaitu BWT (Boiler Water Treatment)
Liquid Plus, Oxygen Control, Condensate Treatment 9-150.

1. Pengujian air ketel teratur

Kualitas air ketel harus secara teratur diuji agar dapat diketahui apakah air tersebut layak digunakan atau harus dilakukan perawatan yang lebih. Begitu pula di MV. NYK Vega, dari hasil observasi dan studi pustaka yang peneliti lakukan, pengujian air ketel dilakukan setiap 2 atau 3 hari sekali secara teratur sesuai dengan jadwal perawatan berkala ketel uap yang terdapat di instruksi manual dan working instruction. Adapun test kit yang digunakan untuk pengujian air ketel di MV. NYK Vega adalah menggunakan NALFLEET Test Equipment.

m. Pasokan chemical dosing unit dari perusahaan terpenuhi

Dari hasil observasi yang peneliti lakukan, chemical dosing unit untuk perawatan air ketel selalu diperhatikan oleh perusahaan. Setiap kali ada permintaan pemasokan chemical dosing yang dikirim dari kapal selalu mendapatkan respon yang baik dari perusahaan, sehingga chemical dosing untuk perawatan air ketel tersebut tidak pernah mengalami kekurangan pasokan. Hal ini sangat berpengaruh dalam usaha membuat kualitas air ketel selalu dalam kondisi baik.

n. Pasokan test kit untuk air ketel dari perusahaan terpenuhi

Dari hasil observasi yang peneliti lakukan, test kit untuk pengujian air ketel selalu diperhatikan oleh perusahaan. Setiap dilakukan permintaan pemasokan test kit yang dikirim dari kapal selalu mendapatkan respon yang baik dari perusahaan, sehingga test kit untuk pengujian air ketel tersebut tidak pernah mengalami kekurangan 
pasokan. Serta setiap bulan dilakukan inventaris untuk menghitung jumlah test kit dan mengetahui tanggal kadaluwarsa test kit tersebut.

o. Dilakukan pengujian air ketel oleh teknisi dari perusahaan

Kualitas air ketel harus secara teratur diuji agar dapat diketahui apakah air tersebut layak digunakan atau harus dilakukan perawatan yang lebih. Dari hasil observasi yang peneliti lakukan, selain pengujian air ketel yang dilakukan oleh cadet mesin atau Masinis 3 di kapal, pengujian air ketel juga dilakukan secara teratur setiap 2 bulan sekali oleh teknisi dari darat yang dikirim oleh perusahaan.

p. Terdapat standar perawatan air ketel dari perusahaan

Dari hasil observasi yang peneliti lakukan, selain standar pengoperasian untuk ketel uap itu sendiri, di MV. NYK Vega terdapat juga standar perawatan air ketel yang disusun oleh pihak perusahaan yang disesuaikan dengan chemical dosing unit yang digunakan di atas kapal.

2. Upaya apa yang dilakukan untuk mengatasi faktor-faktor penyebab menurunnya kualitas air ketel?

Dari faktor-faktor penyebab terjadinya fuel gas trip di atas tersebut dikelompokkan masing-masing berdasarakan metode pengambilan keputusan yaitu SWOT (Strength, Weakness, Opportunities, Threats). Dari faktor tersebut peneliti mengambil penyelesaian terhadap faktor kelemahan (weakness) dan ancaman (threats) yang terjadi ketika peneliti praktek laut sedangkan faktor kekuatan (strength) dan peluang (opportunities) tidak ada penyelesaiannya karena merupakan hal yang positif dan perlu dipertahankan. Adapun faktor-faktor kelemahan dan ancaman tersebut adalah sebagai berikut: a. Air destilasi yang belum banyak tersedia di kapal

Dari hasil observasi dan wawancara yang dilakukan peneliti dengan KKM, penyebab dari gangguan pada FWG tersebut adalah karena bocornya pipa pada evaporator dan rusaknya mechanical seal pada pompa distillate. Adapun upaya yang dilakukan untuk mengatasi masalah tersebut sesuai dengan hasil observasi dan wawancara serta studi pustaka yang peneliti lakukan adalah:

1) Bocornya pipa pada evaporator FWG

Dilakukan pemeriksaan untuk menentukan pipa mana yang bocor, dilakukan penambalan pipa yang bocor menggunakan plug dari tembaga, serta membuka dan menutup katup inlet dan outlet air pemanas evaporator secara perlahan untuk menghindari thermal shock yang dapat menyebabkan kebocoran pipa.

2) Rusaknya mechanical seal pada pompa distillate, dilakukan penggantian mechanical seal pada pompa.

b. Kondisi air tawar dari darat tidak memenuhi syarat untuk air ketel

Dari hasil observasi dan wawancara serta studi pustaka yang dilakukan peneliti, untuk mengatasi masalah tersebut maka dilakukan langkah-langkah sebagai berikut: Dilakukan pengujian air ketel di atas kapal, dilakukan penambahan chemical dosing, serta dilakukan blowdown air ketel.

c. Penginjeksian chemical dosing yang kurang baik

Dari hasil observasi yang dilakukan peneliti, untuk mengatasi masalah tersebut maka dilakukan pembersihan pada filter pipa inlet chemical dosing pump dan 
Dwi Maryuana Restu ${ }^{\mathrm{a}}$, Abdi Seno ${ }^{\mathrm{b}}$ dan Andy Wahyu Hermanto ${ }^{\mathrm{c}}$

pembersihan lubang outlet yang terpasang pada pipa air pengisian. Kemudian menambah feed rate pompa untuk mempercepat proses penginjeksian chemical yang sempat terhambat.

d. Air pengisian kotor

Dari hasil observasi dan wawancara serta studi pustaka yang dilakukan peneliti, untuk mengatasi masalah tersebut maka dilakukan dengan blowdown air dan penambahan chemical.

e. Air kondensat yang belum banyak tersedia di kapal

Dari hasil observasi dan wawancara serta studi pustaka yang dilakukan peneliti, untuk mengatasi masalah tersebut maka dilakukan dengan mengisi cascade tank dengan menggunakan air dari tangki penampungan air tawar, serta dapat ditambahkan air dari hasil proses destilasi dari FWG.

f. Tidak dilakukan pengujian air sebelum air dari darat disuplai ke kapal

Dari hasil observasi dan wawancara serta studi pustaka yang dilakukan peneliti, untuk mengatasi masalah tersebut maka dilakukan pengujian air sesaat setelah digunakan untuk mengisi ketel, sehingga dapat dijadikan pedoman dalam rencana perawatan, seperti penambahan chemical dosing dan pelaksanaan blowdown.

\section{A. Pembahasan Masalah}

1. Faktor Kunci Keberhasilan

a. Faktor Internal dan Eksternal

Setelah didapatkan faktor-faktor yang mendukung maupun yang menyebabkan penurunan kualitas air ketel di MV. NYK Vega, kemudian dikelompokkan dalam tabel faktor internal dan eksternal.
Tabel 1. Faktor Internal dan Eksternal

\begin{tabular}{|c|c|c|c|}
\hline \multicolumn{4}{|c|}{ Faktor Internal } \\
\hline No & Kekuatan (S) & No & Kelemahan (W) \\
\hline 1. & $\begin{array}{l}\text { Air pengisian yang } \\
\text { cukup }\end{array}$ & 1. & $\begin{array}{l}\text { Penginjeksian chemical } \\
\text { dosing yang kurang baik }\end{array}$ \\
\hline 2. & $\begin{array}{l}\text { Terdapatnya SOP yang } \\
\text { baku }\end{array}$ & 2. & Air tawar pengisian kotor \\
\hline 3. & $\begin{array}{l}\text { Pemberian Chemical } \\
\text { Dosing Unit yang sesuai }\end{array}$ & 3. & $\begin{array}{l}\text { Air kondensat yang belum } \\
\text { banyak tersedia di kapal }\end{array}$ \\
\hline 4. & $\begin{array}{l}\text { Pengujian air ketel } \\
\text { teratur }\end{array}$ & 4. & $\begin{array}{l}\text { Air destilasi yang belum } \\
\text { banyak tersedia di kapal }\end{array}$ \\
\hline \multicolumn{4}{|c|}{ Faktor Eksternal } \\
\hline No & Peluang(O) & No & Ancama (T) \\
\hline 1. & $\begin{array}{l}\text { Pasokan chemical } \\
\text { dosing unit dari } \\
\text { perusahaan terpenuhi }\end{array}$ & 1. & $\begin{array}{l}\text { Kondisi air tawar dari } \\
\text { darat tidak memenuhi } \\
\text { syarat untuk air ketel }\end{array}$ \\
\hline 2. & $\begin{array}{l}\text { Pasokan test kit untuk } \\
\text { air ketel dari perusahaan } \\
\text { terpenuhi }\end{array}$ & 2. & $\begin{array}{l}\text { Tidak dilakukan pengujian } \\
\text { air sebelum air dari darat } \\
\text { di supply ke kapal }\end{array}$ \\
\hline 3. & $\begin{array}{l}\text { Dilakukan pengujian air } \\
\text { ketel oleh teknisi dari } \\
\text { perusahaan }\end{array}$ & 3. & Lamanya kapal berlabuh \\
\hline 4. & $\begin{array}{l}\text { Terdapat standard } \\
\text { perawatan air ketel dari } \\
\text { perusahaan }\end{array}$ & 4. & $\begin{array}{l}\text { Pencegahan pencemaran } \\
\text { di sekitar pelabuhan }\end{array}$ \\
\hline
\end{tabular}

\section{b. Komparasi Urgensi Faktor} Internal dan Eksternal

Penilaian terhadap faktor-faktor untuk menentukan Bobot Faktor (BF) dengan membandingkan tiap-tiap faktor pada faktor internal maupun pada faktor eksternal. 
Jurnal Dinamika Bahari

Vol. 8 No. 2 Edisi Mei 2018

Tabel 2. Komparasi Urgensi

\begin{tabular}{|c|c|c|c|c|c|c|c|c|c|c|c|}
\hline a. & E & A. & n & c & $\mathbf{n}$ & $\mathbf{I}$ & $\boldsymbol{r}$ & a & $\mathbf{I r}$ & $x \pi$ & $\pi / \mathbf{s}$ \\
\hline d & & & A & c & 4 & $=$ & 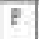 & A & E & 8 & \\
\hline$=$ & 9yea rolo & 2 & & c & D & E & F & 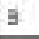 & 日 & & \\
\hline c & ind buenet & c & e & & e & 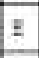 & 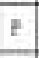 & 0 & $\boldsymbol{A}$ & 3 & bur \\
\hline D & & i & $\mathrm{D}$ & c & & $E$ & E & D & E & & $x: 4$ \\
\hline$\pi$ & ateornt bex & $\pi$ & $\mathrm{r}$ & $\pi$ & I & & $=$ & G & 8 & 5 & 77.96 \\
\hline E & $+\alpha$ & F & $F$ & $\bar{P}$ & f & $E$ & & F & $B$ & 1 & 4.98 \\
\hline G. & & A & $\mathrm{n}$ & G & $\mathrm{D}$ & a & $r$ & & G & 3 & $n$ \\
\hline & telton & $E$ & $\pi$ & 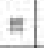 & II & $n$ & I & G & & c & 13 \\
\hline & & 3: & 1 & s & 2 & 3 & 3 & 3 & 6 & 21 & 200 \\
\hline $\mathrm{Pa}$ & & 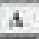 & B & c) & $\mathbf{D}$ & $I$ & $\mathrm{E}$ & G & $\mathrm{H}$ & $\mathrm{xe}$ & Pis \\
\hline a & & & $A$ & a & A & $\mathrm{x}$ & $r$ & E & $\#$ & 3 & int \\
\hline a & 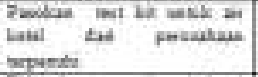 & A. & & 3 & $n$ & $=$ & $r$ & c & E & 1 & \\
\hline c & & 4 & 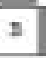 & & $n$ & E & $z$ & G & $\mathbf{z}$ & 0 & . \\
\hline D & & $A$ & t & D & & E & $D$ & c & $z$ & 3 & 72 \\
\hline$=$ & & $=$ & $z$ & $=$ & 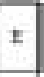 & & $=$ & $=$ & $=$ & 7 & 200 \\
\hline E & octroin win & E & $\boldsymbol{F}$ & F & D & B & & F & ह & 5 & .66 \\
\hline c & 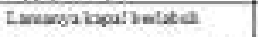 & & & 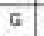 & & -1 & $\sigma^{2}$ & & 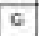 & & \\
\hline E & 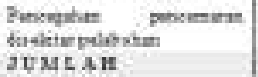 & & $n$ & $=$ & $n$ & $=$ & $r$ & 5 & & a & 201 \\
\hline
\end{tabular}

c. Nilai Dukungan Faktor

Setelah bobot faktor diketahui, berikutnya dilakukan penentuan Nilai Dukungan (ND). Penilaian tersebut penulis dapatkan dari diskusi dengan taruna semester 8 yang dikapalnya terdapat ketel uap. Adapun Nilai Dukung adalah sebagai berikut:

Tabel 3. Nilai Dukungan (ND) Faktor

\begin{tabular}{|c|c|c|}
\hline \multicolumn{2}{|r|}{ FAKTOR INTERNAL } & \multirow{2}{*}{$\frac{\mathrm{xn}}{3}$} \\
\hline$i$ & Air p-11pisiza yank sahyp & \\
\hline 2 & 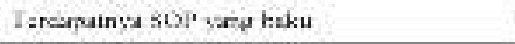 & 3 \\
\hline 3 & 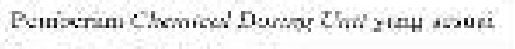 & 4 \\
\hline 4 & Pengujum air tookel ics sour & 3. \\
\hline 5 & 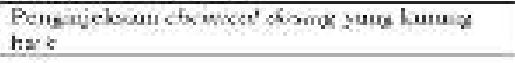 & A \\
\hline$\epsilon$ & Air tamergensisun keter & 4 \\
\hline 7 & 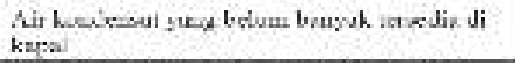 & 4 \\
\hline$x$ & 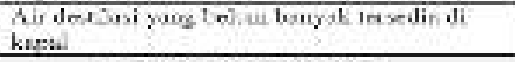 & 4 \\
\hline \multicolumn{2}{|r|}{ TAkTOR FKSTIRNAI. } & vn \\
\hline i & 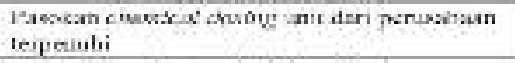 & 2 \\
\hline 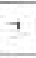 & 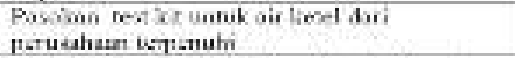 & 7 \\
\hline 3 & 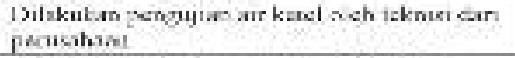 & 1 \\
\hline 1 & 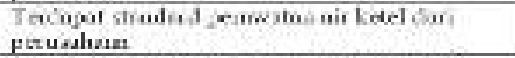 & ; \\
\hline 5 & 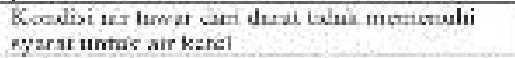 & 1 \\
\hline$\theta$ & 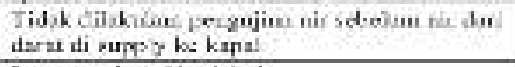 & 3 \\
\hline 7 & Lemanyi krqu. Estuivoh & 3 \\
\hline$x$ & L'snepointe nencemaran crosikiar pelahutan & 3 \\
\hline
\end{tabular}

d. Nilai Relatif Keterkaitan FaktorFaktor

Dengan adanya keterkaitan itulah maka akan tercipta suatu sinergi dalam mendukung misi organisasi. Untuk itu perlu ditentukan Nilai Relatif Keterkaitan (NRK) tiap faktor dengan faktor lainnya. Dalam penilaian didapatkan NRK paling besar pada faktor kelemahan (W) yaitu air destilasi yang kurang tersedia di kapal dengan nilai 3.00, dan faktor ancaman $(\mathrm{T})$ yaitu kondisi air tawar dari darat tidak memenuhi syarat untuk air ketel dengan nilai 2.87 .

e. Matriks Ringkasan Analisis Faktor Internal dan Eksternal

Setelah mendapatkan bobot faktor (BF), nilai dukung (ND) serta nilai relatif keterkaitan (NRK), kemudian langkah selanjutnya adalah penulis menentukan Total Nilai Bobot (TNB).

Tabel 4. Matriks Ringkasan Analisis Faktor Internal dan Eksternal

\begin{tabular}{|c|c|c|c|c|c|c|c|c|c|c|}
\hline sa & IWDOREDEKK WESERKC, & $5 \times$ & $S \mathrm{D}$ & $5 \mathrm{~S}$ & $\operatorname{sen}$ & ST: & SE & $\operatorname{mx}$ & aII. & Du \\
\hline & TWKTCR DURKKK & & & & & & & & & \\
\hline 1 & epapieyepoils & ter & 2 & $e s$ & 2000 & ene & 15 & & \multirow{4}{*}{3} & \multirow{4}{*}{10} \\
\hline I & 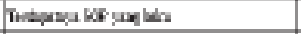 & $2 \mathrm{2}$ & 3 & oul & 26 & ORE & a & & & \\
\hline 2 & 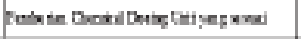 & ten & 4 & ed & 27 & $\cos x$ & 17 & & & \\
\hline 4 & 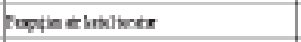 & $\mathrm{ta}$ & 2 & $\mathbf{c a}$ & $w$ & $\sin$ & 16 & & & \\
\hline$\theta$ & 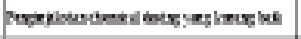 & tT & 4 & $\in \pi$ & 24 & eses & 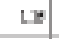 & & \multirow{4}{*}{ क: } & \multirow{4}{*}{494} \\
\hline 6 & 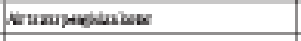 & IE: & 4 & $6: \mathrm{s}$ & 169 & $6.25:$ & 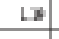 & & & \\
\hline 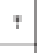 & 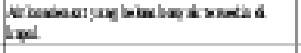 & $6 \mathrm{\pi}$ & 4 & 60 & 24, & $\cos \theta$ & as & & & \\
\hline \multirow[t]{2}{*}{ 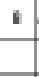 } & 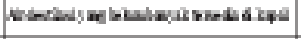 & 20 & 4 & 66 & 260 & $\csc x$ & $L \boldsymbol{x}$ & 1 & & \\
\hline & JWVDREKSIMEXLL. & & & & & & & & & \\
\hline. & 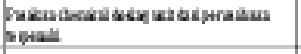 & 14. & a & $\mathbf{m a}$ & 10 & $\operatorname{man}$ & as & & \multirow{4}{*}{$\theta$} & \multirow{4}{*}{ 14: } \\
\hline 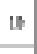 & 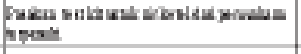 & 20 & 2 & $\mathrm{er}$ & $2 m$ & erst & $n$ & & & \\
\hline u & 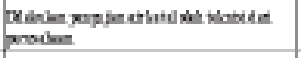 & - & 1 & . & $m$ & 1 & - & & & \\
\hline 12 & 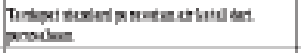 & $\tan$ & 2 & $\mathrm{ex}$ & $1 \mathrm{~A}$ & $\operatorname{six} x$ & 28 & & & \\
\hline is & 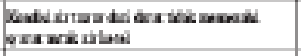 & and & 4 & $1 \boldsymbol{\theta}$ & 169 & exser & เซอ & $\mathrm{t}$ & \multirow{4}{*}{$\mathbf{I}$} & \multirow{4}{*}{48} \\
\hline 4 & 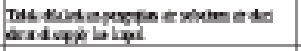 & It: $\mathbf{6}$ & 3 & es: & 12 & exat & aw & & & \\
\hline Ls & Mosulexindalot & $1 \mathrm{tw}$ & 2 & 65: & 247 & 6408. & 38 & & & \\
\hline to & 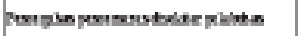 & 40 & 2 & 60 & 10 & esce & sa & & & \\
\hline
\end{tabular}

f. Peta Kuadran Strategi

Dari hasil penilaian terhadap faktor-faktor yang telah disusun di dalam matrik ringkasan analisis 
Dwi Maryuana Restu ${ }^{\mathrm{a}}$, Abdi Seno ${ }^{\mathrm{b}}$ dan Andy Wahyu Hermanto ${ }^{\mathrm{c}}$

faktor internal dan eksternal di atas dapat digunakan untuk menentukan peta kuadran strategi. Adapun peta kuadran strategi tersebut adalah sebagai berikut:

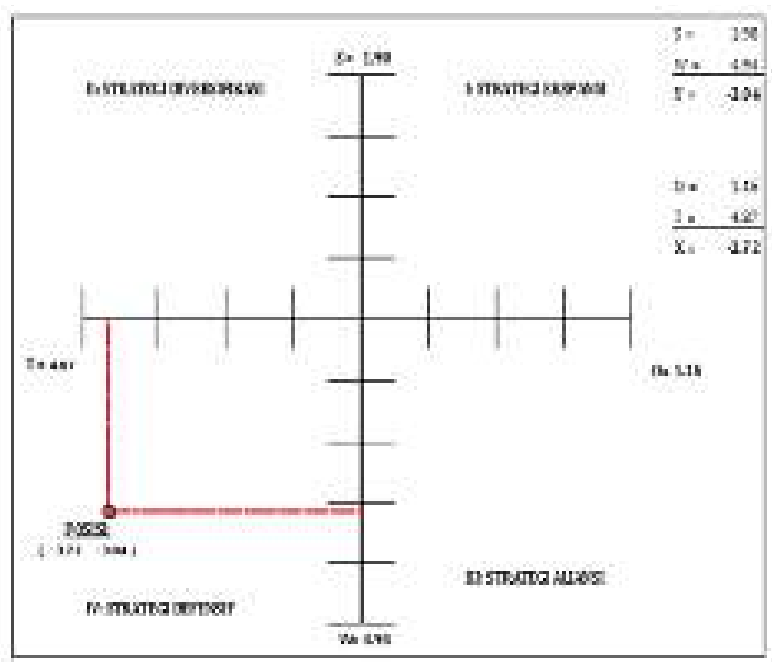

Gambar Peta Kuadran Strategi

Berdasarkan gambar di atas dimana nilai jumlah TNB kekuatan $(\mathrm{S})=1,79$ dan nilai jumlah TNB kelemahan $(\mathrm{W})=4,94$ maka selisihnya $(\mathrm{Y})=\mathrm{S}-\mathrm{W}$ maka hasilya $\mathrm{Y}=-3,15$, sedangkan nilai jumlah TNB peluang $(\mathrm{O})=1,15$ dan nilai jumlah TNB ancaman $(\mathrm{T})=4,87$ maka hasil selisihnya $(\mathrm{X})=\mathrm{O}-\mathrm{T}$ dan hasilnya $-3,73$ maka titik tersebut berada di $(-3,73 ;-3,15)$ atau dapat diketahui bahwa peta kuadran strategi berada di kuadran IV (Strategi Defensive), maka strategi yang dilakukan yaitu mengurangi kelemahan untuk mengatasi ancaman dengan langkah-langkah yang dijelaskan pada bagian upaya yang dilakukan untuk mengatasi faktorfaktor penyebab menurunnya kualitas air ketel, yaitu untuk mengatasi:

a. Air destilasi yang belum banyak tersedia di kapal;

b. Kondisi air tawar dari darat tidak memenuhi syarat untuk air ketel.

\section{KESIMPULAN}

Setelah melaksanakan identifikasi masalah dan dilakukan pembahasan terhadap data yang diperoleh, maka dapat disimpulkan bahwa:

1. Penurunan kualitas air ketel disebabkan oleh dua faktor, yaitu:

a) Air destilasi yang belum banyak tersedia di kapal disebabkan oleh bocornya pipa evaporator pada $F W G$, dan rusaknya mechanical seal pada pompa destilasi yang berdampak pada air destilasi dari tangki yang digunakan untuk mengisi cascade tank menjadi berkurang.

b) Kondisi air tawar dari darat tidak memenuhi syarat untuk air ketel yang disebabkan oleh tidak adamya perawatan khusus dari darat untuk air ketel yang berdampak pada rendahnya kualitas air ketel dari hasil pengujian.

2. Adapun upaya yang dilakukan untuk mengatasi faktor-faktor penyebab menurunnya kualitas air ketel, yaitu:

a) Air destilasi yang belum banyak tersedia di kapal disebabkan oleh bocornya pipa evaporator pada $F W G$ maka dilakukan pemeriksaan untuk menentukan pipa mana yang bocor, dilakukan penambalan pipa yang bocor menggunakan plug dari tembaga, membuka dan menutup katup inlet dan outlet air pemanas evaporator secara perlahan untuk menghindari thermal shock yang dapat menyebabkan kebocoran pipa, sedangkan rusaknya mechanical seal pada pompa destilasi, yaitu dengan dilakukan penggantian mechanical seal pada pompa.

b) Kondisi air tawar dari darat yang tidak memenuhi syarat untuk air ketel yaitu dilakukan pengujian air ketel di atas kapal, dilakukan penambahan 
chemical dosing dan dilakukan blow down terhadap air ketel.

\section{DAFTAR PUSTAKA}

Fatimah, Fajar Nur'aini D. 2016. Teknik Analisis SWOT. Yogyakarta : Quadrant

Handoyo, Jusak Johan. 2016. Ketel Uap, Turbin Uap, dan Turbin Gas Penggerak Utama Kapal. (Edisi 3). Jakarta : Djangkar

Narbuko, Chalid dan Abu Achmadi. 2015. Metode Penelitian. Jakarta : PT Bumi Aksara

Osaka Boiler Mfg. Co., Ltd. 2006. Instruction Manual Book. Jepang

Riandry, Muhammad Aldy. 2014. Air Boiler dan Air Pengisian Boiler. Diambil dari: http://termodinamikablog.blogspot.co. id/2015/04/air-boiler-dan-air-pengisiboiler.html, Diakses pada 02 September 2017

Setiawan, Agus. 2016. Pengertian Studi Kepustakaan, Diambil dari: http://www.transiskom.com/2016/03/ pengertian-studi-kepustakaan.html. Diakses pada 02 September 2017

Sugiyono. 2009. Metode Penelitian Kuantitatif, Kualitatif, dan $R \& D$. Bandung : CV Alfabeta . 2008. Teknik-teknik Analisis Manajemen, Modul Pendidikan dan Pelatihan Kepemimpinan Tingkat III. Jakarta : Lembaga Administrasi Negara
2017. http://lokerpelaut.com/ perawatan-air-keteluap-atauoiler.html. Diakses pada 04 November 2017 